\title{
Value Proposition Canvas: Identification of Pains, Gains and Customer Jobs at Farmers' Markets
}

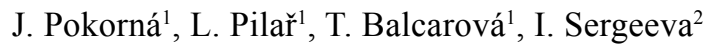 \\ ${ }^{1}$ Department of Management, Faculty of Economics and Management, Czech University of Life Sciences \\ Prague, Czech Republic \\ ${ }^{2}$ Department of Technological Management and Innovations, Chair of Financal Management and Audit, \\ ITMO University, St. Petersburg, Russia
}

\begin{abstract}
Anotace
Cílem výzkumu je identifikovat faktory business modelu utvářející užitnou hodnotu zákazníků farmářských trhu v oblastech (1) Produkty/služby, (2) Generátory zisků and (3) Řešitele problémů. Zjišstované oblasti faktorů vycházejí z metodiky tvorby plátna užitné hodnoty. Primární data byla získána metodou dotazování, osloveno bylo 217 zákazníků farmářských trhů. Dotazník byl šířen osobně. Nejdůležitější úkoly zákazníka byly identifikovány jako zásobit se čerstvými a zdravými potravinami a mít dobrý pocit z nákupu; nejdůležitější generátory zisků jsou čerstvé a zdravé jídlo a nejdůležitějšími problémy jsou vyšší cena a nevhodná otevírací doba. Výstupem je pět obecných doporučení pro prodejce a organizátory trhů. Bylo také zjištěno, že zákazníci farmářských trhů upřednostňují osobní prospěch ve větší míře než faktory s širší společenskou působností.
\end{abstract}

\section{Klíčová slova}

Business model, plátno užitné hodnoty, užitná hodnota zákazníka, farmářské trhy, čerstvé potraviny, agribusiness.

\begin{abstract}
The goal of the research is to identify the factors of business model that form Value Proposition of farmers' market customers in the areas of (1) Products/Services, (2) Gain Creators and (3) Pain Relievers. The examined factor areas are based on the creation of a Value Proposition Canvas. Primary data were acquired through the method of questionnaire survey with 217 customers shopping at the farmer's market. The questionnaire was distributed in person. The most important Customer Jobs are identified as stocking up on fresh and healthy food and feeling good about the purchases; the most important Gain Creators are fresh and healthy food and the most important Pains are higher prices and inconvenient opening hours. Its results are five general recommendations for market sellers and organizers. It was also found that farmers' market customers made personal benefits a greater priority, much more than factors with a wider social scope.
\end{abstract}

\section{Keywords:}

Business model, value proposition canvas, customer's value, farmers' markets, fresh food, agribusiness.

Pokorná, J., Pilař, L., T. Balcarová, T. and Sergeeva, I. (2015) "Value Proposition Canvas: Identification of Pains, Gains and Customer Jobs at Farmers" Markets", AGRIS on-line Papers in Economics and Informatics, Vol. 7, No. 4, pp. 123 - 130, ISSN 1804-1930.

\section{Introduction}

Agricultural production comprises of manufactured goods, generally, food which basically safeguards the physical existence of the population (Vošta, 2014). Within Europe, and EU exactly, the field of food market and problems of food consumption are very important and are highly discussed
(Šrédl, Soukup, 2011). The future development of food markets is bound to the consumer trust in the question of quality. As it is stated by Renting et al. (2003) previously, the food purchases were commonly made in the vicinity or even at home. The customer was noticing the food quality mostly based on personal observation and by social networks within his or her 
neighbourhood. Previous studies identified that the quality is not just dependent on objective product characteristics. Quality is a complex construct of characteristics that are extended to personal needs, such as the safety of food, impact on the environment, support of local rural communities and other ethical aspects (Migliore et al., 2015). However, quality is not the only factor that influences consumer purchases. Food market must be seen as a dynamic market with trends and fashion. Food consumption is also influenced by different lifestyles, consumers' expectations and image that are projected on the food products (Renting et al., 2003). The channel of distribution used for the food production is also one of the important factors.

The retail chains are used as intermediary between the manufacturers and the end consumers (Vošta, 2014). Characteristically all of the fresh production, such as fresh fruits, fresh vegetables, fresh flowers, and live seafood, are perishable goods and need as short time as it gets to get to its final consumers in the postharvest period (Su et al., 2014). Although the food market is gradually more globalized, there is conversely increased pressure on alternate chains which represents the shortest route from the farmer to the final consumer (Renting et al., 2003). Currently, new forms of food distribution channels has been spread. They are defined as short supply chains or short food supply chains (Renting et al., 2003; Migliore et al., 2015). This concept of supply chains covers all actors that are directly involved in the production, processing, distribution, and consumption of new food products and covers also interrelations between them. The difference between short supply chains and conventional industrial mode of food production bring a shortcut from producer to the consumer but through the direct purchases from producers mediate also the authenticity and trust thanks to personal interaction (Renting et al., 2003). Those face-to-face channels consist of farm shops farmers' markets, roadside sales, pick your own, box schemes and also home deliveries (Renting et al., 2003; Migliore et al., 2015). Migliore et al. (2005) also stated that the popularity of short supply chains is growing according to consumers need of fresh plants and at the same time the personal intention to support local farmers. Farmers' markets and locally grown foods in general contribute to the sustainability of the food system by raising the viability of small and medium-sized farms. To enhance the importance of locally grown product differentiation it is crucial to understand consumers' perceptions of the market attributes and venues (Conner et al., 2010). The consumer is seen as an individual that is spending his own resources in order to gain products and services associated with consumption, therefore it is important to learn about his behaviour and decision-making (Šrédl, Soukup, 2011). Farmer's market can be defined as a place where farmers sell their produce directly to consumers. Items frequently sold through farmers' markets are fruits, vegetables, flowers, baked goods, eggs or dairy products. In recent years, farmers' markets have been rapidly spreading due to their ability of meeting the needs of consumers who matter ethical, responsible or green values (Onianwa et al., 2005). By purchasing fresh, organic and local products at farmers' markets, consumers satisfy their current concerns for nutrition, health, well-being, while also supporting local farmers (Cassia et al., 2012). Most consumers in Ohio purchase locally grown food and thus express support for strengthening the local food system (Smith, 2008). For buyers, when it comes to farmers' markets, the quality of the products, supporting local farmers, the price and the environment are key factors (Conner et al., 2010). In farmers' markets, one can observe a rising demand for goods with a high added value. Customers care more about quality, longer durability or special product characteristics (Turčínková and Stávková, 2009). The study with a nationwide sample found that those who frequently buy fresh produce directly from farmers care about high value of product quality, freshness and safety, as well as organic and locally grown products (Bond et al., 2006). Quality perception depends on personal needs, such as food safety, the way in which food is produced in terms of impact on the environment, ethical content such as animal welfare or the area where production takes place (Brown et al., 2009; Dowd, Burke, 2013). Cassia et al. (2012) tests the impact of a perceived customer-company-territory interaction on shoppers' satisfaction. The perceived value is created through the social-economic interactions among customers, local farms and their territory. They found that customers appreciate the intangible value of the perceived customerlocal farmers-local territory interaction, such as the product quality more than they appreciate a low price level. Migliore et al. (2014) in their study identified three types of convention that drives quality perception. Domestic convention refers to direct interaction with the farmer, through which consumers learn about the production system or production traditions. Civic convention is connected with solidarity towards farmers and rural 
communities, they are inspired by social principles of a higher order, for the public good. Regard convention refer to trust that develops after repeated interactions between farmers and customers.

Agribusiness is an important and major sector of any national economy, but the risks of agribusiness are significantly high. According to Dudin et al. (2015), agriculture and all areas including farmer's market could secure their competitive advantages through forming and regular renewal of Business Model Canvas. Business Model Canvas can be defined as: A business model describes the rationale of how an organization creates, delivers, and captures value (Osterwalder, Pigneur, 2010). With his research, Dubin et al. (2015) identified that management concept of Business Model Canvas is designed for managing the strategic sustainable and competitive development of the enterprise structures in the context of the turbulent and unpredictable changes in the market environment. At the centre of the Business Model Canvas is Value Proposition, which represents the value offered to customers (Clark et al., 2012) and can be seen in figure 1. The Value Proposition Canvas makes explicit how you are creating value for your customers. It helps the company design products and services that their customers want (Osterwalder et al., 2014). The creation of the Value Proposition Canvas is based on creating Value Propositions for (1) Product \& Services - what products/services is the value proposition based on (2) Gain Creators - How are they delivering gains? (3) Pain Relievers - How are they killing pains? Using experience in the area of the customer segments of (1) Customer Jobs (2) Gains (3) Pains (Lindič, Silva, 2011).

As it is stated by Šrédl and Soukup (2011), it is important to learn about customer's decision- making. In general, this research is focused on uncovering customers' intentions at the farmer's market as one of the units of the short supply chain. These intentions are used to formulate the Customer's Value Proposition, which is used to design the Business Models of sellers and organizers of farmers' markets. The goal of the research is to identify the factors of business model that form Value Proposition of farmers' market customers in the areas of (1) Products/ Services, (2) Gain Creators and (3) Pain Relievers.

\section{Materials and methods}

The primary data are gathered using the questionnaires. The questionnaire is distributed in person and is intended for customers who have experience with shopping at the farmers' markets. The construction of questionnaire is based on the Business Model Canvas, or more specifically the Customer Value Proposition (Osterwalder et al., 2014). The questionnaire is divided into three parts concerning (1) Products/Services, (2) Gain Creators and (3) Pain Relievers. The questionnaire contains 15 core and 3 identifying questions. Core questions are all open. The questionnaire is completed by a total of 217 customers who visited farmer's market at least once a year at the Czech Republic. Primary data were collected in time period of two months, from May to July 2015 at urban farmer's market located in cities with a population greater than 100,000. Selective statistical set of respondents $(\mathrm{n}=217)$ is represented by the gender: female $(64 \%)$, male $(36 \%)$; by the age: $15-29$ years $(18 \%), 30-44$ years $(39 \%), 45-60$ years (23\%), more than 60 years $(20 \%)$; by farmer's market shopping regularity: more than once a week (21\%), at least once a month (68\%), at least once a year (11\%). Results (Tables 1 - 3)

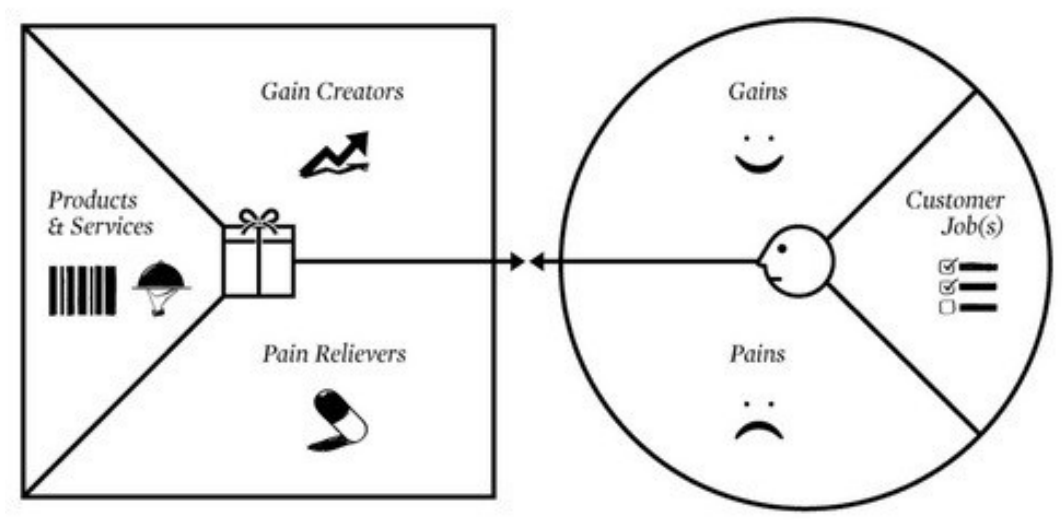

Source: Clark et al., 2012

Figure 1: Value Proposition Canvas. 
contain only those factors which were repeated by the respondents more than 10 times. Customer jobs and Gains are divided by Osterwalder et al. (2012) who distinguished Social, Emotional, Functional and Basic types of factors. The Customer Jobs functional type represents such factors that fulfil the essence and specific purpose of farmer's market visit, such as purchase or stocking up on food. Basic factors are connected to satisfying basic human needs such as eat, sleep, communicate, etc. Social factors are those that are created through interactions with others or are connected to other people. Emotional factors are those that are connected with feelings and are thus related to one's inner perspective. Gains can also be divided in the same way. Functional factors that represent profit coming purely from functional outcomes, tied to the true goal of the customer's behavior. Social ones are such factors when the benefit can be other people's benefit as well. Emotional factors include the outcomes that are connected to arousing certain emotions and not just satisfying the primary shopping goal (Osterwalder et al., 2014). Customers Pains are divided by the authors to those related to product or shopping convenience.

\section{Results and discussion}

In connection to the creation of the Value Proposition Canvas (see Figure 1), the results are grouped into three areas. The tables contain the absolute and relative frequency of the identified factors and the factor type.

The main Customer Jobs in Table 1, which influence the customer while shopping at the farmer's market, belong to the Functional as well as Social and Emotional types. At farmers' markets, they most often stock up on fresh and healthy food (59 \%), which belongs to the Functional factors. The second most frequent factor is the good feeling they get from shopping (43\%), which belongs to the Emotional factors. Feeling good is connected to other types of factors, as the respondents stated. They feel good about buying fresh, healthy and high quality food. They perceive the quality of the products primarily in using appropriate ingredients. The third most frequent factor represent eating fresh food $(20 \%)$ and it is classified among Basic factors. The fourth factor represents protecting the family and its health by buying fresh and healthy food $(20 \%)$ and belongs to the Social factors. Other factors in the Table 1 have a frequency of $10 \%$ or under. Nevertheless, the factor that is one of the least frequent - buying specialty goods (4\%), confirms the conclusions of previous research. Farmer's market produce items were more frequently local and organic, but often tended toward less common or more exotic and heirloom varieties (Lucan et al., 2015).

The main Gains of shopping at farmers' markets are fresh and healthy food ( $72 \%$ and $62 \%$, see Table 2$)$. These two factors can be considered as a part of Functional factors, which are directly connected to the food bought at farmers' markets. The other groups that form Gains are Social-Emotional factors, such as sellers' recommendations (the seller's more personal approach), a good feeling from supporting local producers and stylish packaging. Despite their low frequency in the respondents' answers, these factors are very important in terms of the Value Proposition creation, because they have an influence on the overall value that the customer gains from shopping at farmers' markets.

Based on the interviews, 10 factors that respondents connect to negative feelings, risk or unsolicited costs before, during or after shopping at farmers' markets were identified (see Table 3). The most frequently mentioned factor $(53 \%)$ is higher prices

\begin{tabular}{lccc}
\hline Factors & Absolute frequency & Relative frequency & Type of factors \\
\hline Stocking up on fresh and healthy food & 128 & $59.10 \%$ & Functional \\
\hline Feeling good about the purchase & 94 & $43.40 \%$ & Emotional \\
\hline Eating fresh and healthy food & 44 & $20.10 \%$ & Basic, Functional \\
\hline Protecting family and its health & 43 & $19.79 \%$ & Social \\
\hline Satisfying curiosity & 26 & $12.13 \%$ & Emotional \\
\hline Spending free time & 15 & $7.02 \%$ & Emotional \\
\hline Looking modern/trendy & 13 & $6.06 \%$ & Social \\
\hline Learning something & 11 & $5.07 \%$ & Functional, Emotional \\
\hline Buying specialty goods & 10 & $4.47 \%$ & Functional \\
\hline Source: own calculations based on questionnaire survey, 2015 & & \\
\end{tabular}




\begin{tabular}{lccc}
\hline Factors & Absolute frequency & Relative frequency & Type of factors \\
\hline Fresh food & 157 & $72.34 \%$ & Functional \\
\hline Healthy food & 141 & $64.98 \%$ & Functional \\
\hline $\begin{array}{l}\text { Sellers' recommendations } \\
\text { (seller's more personal approach) }\end{array}$ & 79 & $33.64 \%$ & Social/Emotional \\
\hline Good feeling about supporting local producers & 44 & $20.28 \%$ & Social \\
\hline Stylish packaging & 12 & $5.52 \%$ & $\begin{array}{c}\text { Social/Emotional/ } \\
\text { Functional }\end{array}$ \\
\hline
\end{tabular}

Source: own calculations based on questionnaire survey, 2015

Table 2: The most frequent Gains of farmers' market customers.

\begin{tabular}{lccc}
\hline Factors & Absolute frequency & Relative frequency & Type of factors \\
\hline Higher prices & 167 & $53,29 \%$ & Product \\
\hline Inconvenient opening hours & 123 & $39,25 \%$ & Convenience \\
\hline Not enough information on the source of the goods & 92 & $29,36 \%$ & Product \\
\hline Anonymity of the farmers & 87 & $27,76 \%$ & Product \\
\hline No parking & 58 & $18,51 \%$ & Convenience \\
\hline Queues & 43 & $13,72 \%$ & Convenience \\
\hline No card payments & 40 & $12,76 \%$ & Convenience \\
\hline No returns & 32 & $10,21 \%$ & Convenience \\
\hline No restrooms & 23 & $7,34 \%$ & Convenience \\
\hline No rest areas & 15 & $4,79 \%$ & Convenience \\
\hline
\end{tabular}

Source: own calculations based on questionnaire survey, 2015

Table 3: The most frequent Pains of farmers' market customers.

of goods compared to, for example, supermarket prices, which is a factor connected to the product. An important factor is also the inconvenient opening hours (39\%), which is the most important factor in the shopping convenience. Other important factors are insufficient information on the source of the goods $(29 \%)$ or the farmer's anonymity (28\%), which are also tied to the product. In contrast, the negative factor that the respondents stated as the least important was the absence of restrooms $(7 \%)$ or rest areas (5\%), which, together with other factors, belong to the customer's shopping convenience.

In terms of the Customer Jobs identified in our research, customers focus more on their own benefit and buying high quality goods in the first place. This is in accordance with the growing demand for food with a high added value as stated by Turčínková and Stávková (2009). The customer is focused on his or her own profit and his or her values are mostly connected to Functional factors and those Social and Emotional factors that are linked to the customer as a person or his or her family. Factors from the Gains area can be also aggregated to Functional, Social and Emotional types factors. Functional factors express profit in the form of fresh and healthy food. These factors are considered by the customers as the most important and belong to the main values that will make the customer decide to shop at farmers' markets. The Functional type of the Gain area focuses on fresh and healthy food. This is in accordance with the research (Bond et al., 2006) stating that the high value of high quality product is freshness and safety, as well as organic and locally grown products. In non-functional area, an important factor was also sellers' recommendations, which can be part of the social and emotional type of factors that supports the findings of the research conducted by Renting et al. (2003). Customers often prefer farmers' markets because they can interact directly with the producer/grower, who can give them recommendations or other information. Nevertheless, it must be noted that $20 \%$ of the respondents mentioned the factor of support for local producers. When comparing the research with other current published studies, two significant differences were revealed. The emerged socialemotional factor of stylish packaging signified the farmers' markets customers' desire for a certain social status. Respondents confirm that shopping at farmers' markets is fashionable. The question is, if one of the sellers had purposefully taken advantage of the customers' desire to strengthen 
their social status, would that thereby raised both customers' interest and farmer's competitiveness. The main cause of uncomfortable feelings about shopping at farmers' markets is the higher price of the goods. Perceiving the higher prices is confirmed by research (Lucan et al., 2015), showing that farmers' markets were more expensive on average ( $p$ values $<0.001$ for pairwise comparisons to stores) especially when discounts or sales prices were considered. In general, respondents mentioned factors connected to the product, such as the price or the origin, when asked about the source of the bad feeling before, during and after shopping. Factors related to shopping convenience, with the exception of inconvenient opening hours (39\%), were under $20 \%$ (queues, not being able to pay with a card, no returns, etc.). Inconvenient opening hours are related to the fact that farmers' markets were open substantially fewer months, days, and hours than stores (Lucan et al., 2015).

Scholars stated, that customers' values of purchasing goods are more aimed at social issues, such as supporting local farmers, strengthening local food systems or other ethical, responsible or green values (Onianwa et al., 2005; Cassia et al., 2012; Smith, 2008; Conner et al., 2010). However, in this research the lower frequency of such issues was identified in comparison with functional factors and those social factors tied to personal profit. The absence of factors with wider social scope or ethical content, such as animal welfare," that was identified in Central England and Southern France (Brown et al., 2009) and Australia (Dowd, Burke, 2013) is surprising. This factor wasn't even mentioned by any of the 217 respondents, which indicates that, as has been already mentioned, the customers' focus on social and emotional factors connected to their own personal profit, or the profit of their family.

\section{Conclusion}

The main purpose of this study was to identify factors that create value for the customer who does the shopping at farmers' markets. Other authors (Conner et al., 2010) primarily analyse the environment of farmers' markets in general, which is in this research in context of the Value Proposition Canvas included in the Customer Jobs and Gains areas in detail. This study mainly contributes to the previous researches with an extension of the Pain area and its factors. In our interviews respondents also related specific constrains that negatively influence them when they shop at farmers' markets and thus decrease the overall value perceived by the customer. The research further discovered that social and emotional factors are directed at the customer's personal profit (feeling good for buying high quality food, protecting one's own family, learning something, spending one's free time, etc.) much more than factors with a wider social scope (welfare, supporting local communities). The research conducted has produced recommendations for individual sellers at farmers' markets as well as for organizers. One can suggest to organizers especially to minimize customers' negative perceptions of the sales environment. Therefore, it can be recommended:

- Communicate the quality of the products especially by emphasizing their freshness and healthiness, i.e. visibly present these qualities to customers on signs.

- Use personal contact to inform the customer, provide extra information on the qualities of the products, the way to use/prepare them, make recommendations and give additional information.

- Provide customers with basic information on the origin of the goods and the farmers, in the case of a local producer it's also advantageous to communicate these facts.

- Respondents mentioned the original and stylish packaging of the farmers' products as a factor that raises customer's value.

- Organizers should inform customers on parking options in the area or consider possibilities of providing the rest area.

One can distinguish customers' perceptions of farmers' markets by their environment and the product quality. The customers weigh the parameters of the market and the services that the location offers as well as the quality of the products for which they need information. Future research should focus on identifying factors that form the value proposition of shopping at the supermarket and compare those factors to findings of this research focused on farmers' markets.

\section{Acknowledgments}

The research was supported by the Internal Grant Agency (IGA n. 20141018), Faculty of Economics and Management, Czech University of Life Sciences Prague. 


\section{Corresponding author:}

Ing. Jitka Pokorná, Ph.D.

Department of Management, Faculty of Economics and Management

Czech university of Life Sciences Prague, Kamýcká 129, 16521 Prague 6, Czech Republic

Phone:+420224382239,E-mail: pokornaj@pef.czu.cz

\section{References}

[1] Bond, J. K., Thilmany, D., Bond, C. A. Direct Market Purchases of Fresh Produce: Understanding Consumer Purchasing Decisions. Choices. 2006, Vol. 21, No.4, p. 229 - 236. ISSN 0886-5558.

[2] Brown, E., Dury, S., Holdsworth, M. Motivations of consumers that use local, organic fruit and vegetable box schemes in Central England and Southern France. Appetite. 2009, Vol 53, No. 2, p. 183-188. DOI:10.1016/j.appet.2009.06.006. ISSN 0195-6663.

[3] Cassia, F., Ugolini, M., Bonfanti, A., Cappellar, C. The Perceptions of Italian Farmers' Market Shoppers and Strategic Directions for Customer-Company-territory Interaction (CCTI). Procedia - Social and Behavioral Sciences $8^{\text {th }}$ International Strategic Management Conference. 2012, Vol. 58, p. 1008 - 1017. DOI:10.1016/j.sbspro.2012.09.108. ISSN 1877-0428.

[4] Clark, T., Osterwalder, A., Pigneur, Y. Business Model You: A One-Page Method For Reinventing Your Career, Wiley, London, 2012. 264 p., ISBN: 978-1118156315.

[5] Conner, D., Colasanti, K., Brent Ross, R., Smalley B. S. Locally Grown Foods and Farmers' Markets: Consumer Attitudes and Behaviors. Sustainability. 2010, Vol. 2, p. 742-756. DOI:10.3390/ su2030742. ISSN 2071-1050.

[6] Dowd, K., Burke, K. J. The influence of ethical values and food choice motivations on intentions to purchase sustainably sourced foods. Appetite. 2013, Vol. 69, p. 137-144. DOI:10.1016/j.appet.2013.05.024. ISSN 0195-6663.

[7] Dubin, M. N., Lyasnikov, N. V., Leont'eva, L. S., Resherov, L. J., Sidorenko, V. N. Business Model Canvas as a Basis for the Competitive Advantage of Enterprise structures in the Industrial Agriculture. Biosciences Biotechnology Research Asia. 2015, Vol. 12, No. 1, p. 887 - 894. DOI:10.13005/bbra/1736. ISSN 0973-1245.

[8] Lindič, J., Marques da Silvam C. Value proposition as a catalyst for a customer focused innovation. Management Decision. 2011, Vol. 49, No. 10, p. 1694 - 1708. DOI:dx.doi.org/10.1108/00251741111183834. ISSN 0025-1747.

[9] Lucan, C. S., Maroko, A. R., Sanon, O., Frias, R., Schechter, B. C. Urban farmers' markets: Accessibility, offerings, and produce variety, quality, and price compared to nearby stores. Appetite. 2015, Vol. 90, p. 23-30. DOI:10.1016/j.appet.2015.02.034. ISSN 0195-6663.

[10] Migliore, G., Schifani, G., Cembalo, L. Opening the black box of food quality in the short supply chain: Effects of conventions of quality on consumer choice. Food Quality and Preference. 2015, Vol. 39, pp. 141-146. DOI:10.1016/j.foodqual.2014.07.006. ISSN 0950-3293.

[11] Onianwa, O., Wheelock, G., Mojica, M. An Analysis of the Determinants of Farmer-to-Consumer Direct-Market Shoppers. Journal of Food Distribution Research. 2005, Vol. 36, No. 1, p. 130-134.

[12] Osterwalder, A., Pigneur, Y., Bernarda, G., Smith, A., Papadakos, T. Value proposition design: how to create products and services customers want. Wiley, London, 2014. 320 p. ISBN 978-1-118-96805-5.

[13] Osterwalder, A., Pigneur, Y. Business model generation: a handbook forvisionaries, game changers, and challengers. Wiley, London, 2010. 72 p. ISBN 978-0470876411.

[14] Renting, H., Marsden, T. K., Banks, J. Understanding alternative food networks: exploring the role of short food supply chains in rural development. Environment and Planning. 2003, Vol. 35, p. 393 - 411. DOI:10.1068/a3510. ISSN 0308-518X. 
[15] Smith, B. M., Sharp, J. S. A Current and Retrospective Look at Local Food Consumption and Support among Ohioans. Agricultural and Environmental Issues. 2008, The Ohio State University: Columbus, OH, USA.

[16] Su, J., Wu, J., Liu, Ch. Research on Coordination of Fresh Produce Supply Chain in Big Market Sales Environment. The Scientific World Journal. 2014, Vol., p. 1 - 12. DOI:doi.org/10.1155/2014/873980. ISSN 2356-6140, E-ISSN 1537-744X.

[17] Šrédl, K., Soukup, A. Consumer's behaviour on food markets. Agricultural Economics. 2011, Vol. 57, No. 3, p. 140 - 144. ISSN 0139-570X.

[18] Turčínková, J., Stávková, J. Changes in consumer behavior on the market with food, Acta Univ. Agric. Silvic. Mendelianae Brun. 2009, Vol. 57, No 3, p. 173 - 178. DOI:10.11118/actaun200957030173. ISSN 1211-8516.

[19] Vošta, M. The food market in the CR and its regulation within the framework of the EU agricultural policy. Agricultural Economics. 2014, Vol. 60, No. 6, p. 279 - 286. ISSN 0139-570X. 